\title{
Mango Fruit Extracts Differentially Affect Proliferation and Intracellular Calcium Signalling in MCF-7 Human Breast Cancer Cells
}

\author{
Meng-Wong Taing, ${ }^{1}$ Jean-Thomas Pierson, ${ }^{1}$ Paul N. Shaw, ${ }^{1}$ Ralf G. Dietzgen, ${ }^{1,2}$ \\ Sarah J. Roberts-Thomson, ${ }^{1}$ Michael J. Gidley, ${ }^{2}$ and Gregory R. Monteith ${ }^{1}$ \\ ${ }^{1}$ School of Pharmacy, The University of Queensland, Brisbane, QLD 4072, Australia \\ ${ }^{2}$ Queensland Alliance for Agriculture and Food Innovation, Centre for Nutrition and Food Sciences, \\ The University of Queensland, Brisbane, QLD 4072, Australia
}

Correspondence should be addressed to Gregory R. Monteith; greg@pharmacy.uq.edu.au

Received 1 December 2014; Accepted 7 January 2015

Academic Editor: Artur M. S. Silva

Copyright (C) 2015 Meng-Wong Taing et al. This is an open access article distributed under the Creative Commons Attribution License, which permits unrestricted use, distribution, and reproduction in any medium, provided the original work is properly cited.

\begin{abstract}
The assessment of human cancer cell proliferation is a common approach in identifying plant extracts that have potential bioactive effects. In this study, we tested the hypothesis that methanolic extracts of peel and flesh from three archetypal mango cultivars, Irwin (IW), Nam Doc Mai (NDM), and Kensington Pride (KP), differentially affect proliferation, extracellular signal-regulated kinase (ERK) activity, and intracellular calcium $\left(\left[\mathrm{Ca}^{2+}\right]_{\mathrm{I}}\right.$ ) signalling in MCF-7 human breast cancer cells. Mango flesh extracts from all three cultivars did not inhibit cell growth, and of the peel extracts only NDM reduced MCF-7 cell proliferation. Mango cultivar peel and flesh extracts did not significantly change ERK phosphorylation compared to controls; however, some reduced relative maximal peak $\left[\mathrm{Ca}^{2+}\right]_{\mathrm{I}}$ after adenosine triphosphate stimulation, with NDM peel extract having the greatest effect among the treatments. Our results identify mango interfruit and intrafruit (peel and flesh) extract variability in antiproliferative effects and $\left[\mathrm{Ca}^{2+}\right]_{\mathrm{I}}$ signalling in MCF-7 breast cancer cells and highlight that parts of the fruit (such as peel and flesh) and cultivar differences are important factors to consider when assessing potential chemopreventive bioactive compounds in plants extracts.
\end{abstract}

\section{Introduction}

Driven by consumer interest in the relationship between food and health, an increasing number of studies are focusing on the nutritional benefits derived from fruits and vegetables. It is postulated that the regular consumption of fruits and vegetables can reduce the risk of specific cancers, due to the presence of highly concentrated and diverse chemopreventive phytochemicals. Research has identified that dietary phytochemicals present within natural plant sources such as broccoli, ginger, turmeric, tomatoes, and grapes can modulate one or more signal transduction pathways involved in cancer cell survival to inhibit cell viability and metastasis and induce apoptosis $[1,2]$. Studies exploring potential chemopreventive agents within tropical fruits, however, remain limited [3].

Mangoes (Mangifera indica L.) are a tropical fruit commercially grown for worldwide export and distribution [4].
Many different mango cultivars exist with a large diversity between fruit phenotypes (shape, colour, size, and texture) and flavours (taste and aroma) [4]. These differences between cultivars suggest possible variation in the composition of the fruit's phytochemicals, some of which may have potent biological activities [5]. Noratto et al. recently demonstrated differential growth inhibitory activities of extracts from diverse mango cultivars in SW-480 colon cancer cells [6,7]. Different parts of the mango fruit (such as the peel and flesh) also have variable bioactive effects and these differences are likely due to differences in the type and amounts of phytochemicals present within each tissue [7]. For example, we have previously reported that only the peel portion, rather than the flesh of mango fruit, affects adipogenesis in 3T3-L1 cells [7].

Studies in vitro and in vivo associate the effects of natural dietary products on cancer cells $[8,9]$. Phytochemical compounds, some of which have antioxidant activity, also have 
diverse chemopreventive roles including inhibitory effects on growth and metastatic potential [10] as well as induction of cell death and differentiation [11]. A mechanism by which phytochemicals exert their chemopreventive action may be through their effects on signalling pathways important in cancer progression $[8,12]$.

The assessment of proliferation in human cancer cell lines is a proven approach to identify foods and compounds with promising chemopreventive activities [11, 13]. Many signalling pathways are implicated in cellular proliferation, including extracellular signal-regulated kinase (ERK), and changes in intracellular calcium $\left(\left[\mathrm{Ca}^{2+}\right]_{\mathrm{I}}\right)[12,14]$. ERK activation regulates several transcription factors promoting cell growth, apoptosis, and metastasis [14]. In MCF-7 breast cancer cells the ERK pathway is activated by proliferative stimuli including oestrogen, prolactin, and epidermal growth factor [15-17], whereas the soy-derived isoflavone, genistein, contributes to growth inhibitory effects in breast and prostate cancer cells, in part through attenuation of ERK activity $[12,18]$. Cytoplasmic calcium regulation is also implicated in tumorigenesis [19]. Increases in $\left[\mathrm{Ca}^{2+}\right]_{\mathrm{I}}$ can activate multiple proliferative pathways including the calcium/calmodulindependent kinase family of proteins that promote the growth and proliferation of human breast epithelial cells [14]. Regulators of intracellular free $\mathrm{Ca}^{2+}$ homeostasis include plantderived compounds such as inhibitors of the sarcoendoplasmic reticulum $\mathrm{Ca}^{2+}$-ATPase (SERCA), for example, thapsigargin from Thapsia garganica L. and curcumin derived from turmeric (Curcuma longa L.). Natural modulators of $\mathrm{Ca}^{2+}$ permeable ion channels also exist in plants $[20,21]$ and include the TRPM8 activator menthol present in peppermint (Mentha $\times$ piperita L.) and the TRPV1 activator capsaicin present in chili peppers (Capsicum spp.) [22, 23]. Both TRPM8 and TRPV1 have been proposed as targets in breast and prostate cancer therapy [19]. In this study, we tested the hypothesis that peel and flesh extracts from three genetically distinct mango cultivars [24] have distinct antiproliferative effects on MCF-7 breast cancer cells and examined two pathways linked to tumor progression (ERK activity and $\mathrm{Ca}^{2+}$ signalling). Our study is the first to report mango fruit extract effects on $\mathrm{Ca}^{2+}$ signalling in MCF-7 breast cancer cells.

\section{Materials and Methods}

2.1. Cell Culture. MCF-7 human breast cancer cells were maintained in Dulbecco's Modified Eagle's Medium (DMEM, Sigma-Aldrich, St. Louis, MO, USA) supplemented with $10 \%$ fetal bovine serum (FBS, SAFC Biosciences, Lenexa, KA, USA), 4 mM L-glutamine, and penicillin G (100 U/mL) and streptomycin $(100 \mu \mathrm{g} / \mathrm{mL})$ (PSG, Gibco, Grand Island, NY, USA). Cells were plated in $75 \mathrm{~cm}^{2}$ tissue culture flasks and incubated in a $5 \% \mathrm{CO}_{2}$ humidified incubator at $37^{\circ} \mathrm{C}$. Cell culture medium was replaced every second day. In all experiments, cells were used at a passage number not exceeding 10 after thawing from stocks maintained in liquid $\mathrm{N}_{2}$. MCF-7 cells were routinely assessed for mycoplasma contamination using the MycoAlert Detection Kit (Lonza, Mt Waverley, Australia).
2.2. Preparation of Mango Extracts. Mango fruit from three genetically distinct cultivars [4, 25] Irwin (IW), Nam Doc Mai (NDM), and Kensington Pride (KP) were collected from the Australian National Mango Genebank [24] maintained by the Queensland Department of Agriculture, Fisheries and Forestry at Southedge Research Station, Queensland, Australia. Green mature fruits were picked from several trees grown on light granitic soil and were stored at $20^{\circ} \mathrm{C}$ until they reached consumption ripeness as assessed by the sprung test [26]. The weights of KP fruit were on average $500 \mathrm{~g}$, NDM $250 \mathrm{~g}$, and IW $350 \mathrm{~g}$. The peel was separated from the fleshapproximately $200 \mathrm{~g}$ of pulp and $60 \mathrm{~g}$ of peel were derived from each cultivar fruit and both parts were cryodesiccated and ground to a powder using a mortar and pestle. The extraction process was adapted from a previously published method [27]. In brief, freeze-dried powder (25 g) from each cultivar was refluxed for $6 \mathrm{~h}$ using two solvents, hexane and methanol, sequentially. The hexane solvent removed highly nonpolar compounds such as carotenoids. Polyphenolics were extracted using methanol as the solvent. Methanolic extracts were then acidified $(\mathrm{pH} \mathrm{2-4)}$ by the addition of hydrochloric acid, and the acidified solution was further extracted using ethyl acetate. Under reduced pressure, pooled extracts were lyophilized and stored at $4^{\circ} \mathrm{C}$.

2.3. Assessment of Cell Viability Using MTS Assay. MCF7 breast cancer cell viability was measured using the Cell Titer 96 AQ Ueous One Solution Cell Proliferation (MTS) Assay (Promega, Madison, WI, USA). The MTS assay is a widely used technique for determination of cell viability [28-30]. Cells were seeded at a density of 7.5-10 $\times 10^{3}$ cells per well in a 96 well microplate (day 0) and incubated overnight at $37^{\circ} \mathrm{C}$. Media were replaced on days 1 and 3 with either vehicle control, serum free media, or media containing mango extracts (peel 3, 10, 30, and $100 \mu \mathrm{g} / \mathrm{mL}$; flesh 3, 10, 30, and $100 \mu \mathrm{g} / \mathrm{mL}$ ) prepared to a final DMSO concentration of $0.65 \% \mathrm{v} / \mathrm{v}$. At day 5 , an MTS assay was performed according to manufacturer's protocol and as previously described [31]. In brief, MTS reagent $(20 \mu \mathrm{L})$ was dispensed into each well of a 96 well microplate and incubated at $37^{\circ} \mathrm{C}$ for $2 \mathrm{~h}$. Absorbance was measured and recorded at $490 \mathrm{~nm}$ using a BioRad iMark Microplate reader.

2.4. Immunoblotting. MCF-7 cells were plated at $7.5 \times 10^{5}$ cells per well in 6-well plates and incubated overnight at $37^{\circ} \mathrm{C}$. MCF-7 cells were serum starved for $24 \mathrm{~h}$ and then treated with vehicle control $(0.65 \% \mathrm{v} / \mathrm{v}$ DMSO in medium) or mango peel and flesh extracts $(60 \mu \mathrm{g} / \mathrm{mL}$ in medium $)$ for $2 \mathrm{~h}$ before stimulation with $100 \mathrm{nM}$ phorbol 12-myristate 13acetate (PMA, Sigma-Aldrich, St. Louis, MO, USA) for $15 \mathrm{~min}$ to induce ERK phosphorylation as previously reported [10]. Cell extracts were generated on ice with protein lysis buffer supplemented with phosphatase and protease inhibitors (Roche Applied Science, Indianapolis, IN, USA). Cell lysates were separated on $4-12 \%$ gradient bis-tris gels with MOPS electrophoresis buffer (Invitrogen, Carlsbad, CA, USA) and then transferred to a polyvinylidene fluoride (PVDF) membrane (Invitrogen). Nonfat milk powder $(5 \% \mathrm{w} / \mathrm{v})$ in PBS 
with $0.1 \% \mathrm{w} / \mathrm{v}$ Tween-20 (Sigma-Aldrich) was used to block membranes for $1 \mathrm{~h}$ at room temperature. Membranes were then probed using mouse monoclonal anti-phospho-ERK1/2, rabbit polyclonal anti-ERK1/2 (Cell Signalling Technology, Danvers, MA, USA), and mouse monoclonal $\beta$-actin (SigmaAldrich). Anti-phospho-ERK1/2 primary antibody $(1: 2000)$ anti-ERK1/2 $(1: 1000)$ and $\beta$-actin $(1: 10,000)$ were incubated overnight with membranes at $4^{\circ} \mathrm{C}$. Bands were visualized by chemiluminescence using anti-rabbit or anti-mouse horseradish peroxidase-conjugated secondary antibodies at 1:10,000 dilution (BioRad, Hercules, CA, USA). A Versadoc Imaging System was used to acquire images and bands were quantified using Bio-Rad Quantity One Software. Phosphorylated ERK protein was quantified relative to total ERK protein expression; total ERK levels were normalized to those of $\beta$-actin.

2.5. Calcium Assays. Alterations in intracellular free $\mathrm{Ca}^{2+}$ responses associated with mango extracts were assessed using a fluorometric imaging plate reader (FLIPR ${ }^{\text {TETRA }}$, Molecular Devices, Sunnyvale, CA, USA). MCF-7 breast cancer cells were plated at $1 \times 10^{4}$ cells per well in 96 well black walled clear bottom plates (CellBIND Surface, Corning, Lowell, MA, USA). At days 1 and 3 of incubation, culture medium was replaced with medium containing control vehicle $(0.65 \%$ $\mathrm{v} / \mathrm{v}$ DMSO) or mango peel $(30,60 \mu \mathrm{g} / \mathrm{mL})$ and flesh $(30$, $60 \mu \mathrm{g} / \mathrm{mL}$ ) extracts prepared to a final concentration of $0.65 \%$ v/v DMSO in cell culture medium. On day 5, each well was loaded with Fluo-4 AM ( $4 \mu \mathrm{M}$, Invitrogen) in medium supplemented with $0.1 \% \mathrm{v} / \mathrm{v}$ DMSO, for $30 \mathrm{~min}$ at $37^{\circ} \mathrm{C}$. The loading solution was replaced with physiological salt solution (PSS, pH 7.2) containing $5.9 \mathrm{mM} \mathrm{KCl}, 1.4 \mathrm{mM} \mathrm{MgCl}_{2}, 1.2 \mathrm{mM}$ $\mathrm{NaH}_{2} \mathrm{PO}_{4}, 10 \mathrm{mM}$ HEPES, $5 \mathrm{mM} \mathrm{NaHCO}{ }_{3}, 140 \mathrm{mM} \mathrm{NaCl}$, $11.5 \mathrm{mM}$ glucose, and $1.8 \mathrm{mM} \mathrm{CaCl}_{2}$. The purinergic receptor activator adenosine triphosphate (ATP) was added at a final concentration of $100 \mu \mathrm{M}$ and $\left[\mathrm{Ca}^{2+}\right]_{\mathrm{I}}$ measurements were performed with 470/95 and 515/75 emission and excitation filters, respectively. Fluorescence values were normalized to baseline fluorescence and expressed as relative $\left[\mathrm{Ca}^{2+}\right]_{\mathrm{I}}$ and maximal relative $\left[\mathrm{Ca}^{2+}\right]_{\mathrm{I}}$.

\section{Results}

3.1. Effect of Mango Peel and Flesh Extracts from Three Genetically Distinct Cultivars on the Viability of MCF-7 Breast Cancer Cells. Mango peel and flesh extracts (3, 10, 30, and $100 \mu \mathrm{g} / \mathrm{mL}$ ) from three cultivars (IW, NDM, and KP) were assessed for their effects on MCF-7 cell viability. As expected, cells grown for five days in medium containing no serum had significantly reduced viability when compared to control cells (Figures 1(a), 1(b), and 1(c)). NDM peel extract $(100 \mu \mathrm{g} / \mathrm{mL})$ also significantly reduced the number of viable cells (Figure 1(b)) whereas IW and KP peel extracts did not affect cell viability (Figures $1(\mathrm{a})$ and $1(\mathrm{c})$ ). Regardless of cultivar, mango flesh extracts did not affect MCF-7 cell viability. from the peel or flesh of the three different mango cultivars could alter ERK phosphorylation. MCF-7 cells were treated with mango peel and flesh extracts (at $60 \mu \mathrm{g} / \mathrm{mL}$ ) from the IW, NDM, and KP cultivars for $2 \mathrm{~h}$ and then stimulated with PMA (100 nM) for $15 \mathrm{~min}$ to induce phosphorylation of ERK1/2 in MCF-7 cells. In the absence of PMA, ERK 1/2 phosphorylation was absent (Figures 2(a) and 2(c)), whereas ERK1/2 was phosphorylated in response to PMA treatment (control, Figures 2(a) and 2(c)). MCF-7 cells treated with IW, KP, and NDM peel extracts did not significantly alter ERK1/2 phosphorylation (Figure 2(a)). An assessment of total ERK1/2 levels between different treatment groups showed similar levels compared to PMA treated control (Figure 2(b)).

Treatment of MCF-7 cells with mango flesh extracts from IW, KP, and NDM did not significantly alter ERK1/2 activity compared to PMA-treated control (Figure 2(c)). The total ERK1/2 levels were also compared to PMA-treated control and were not significantly different (Figure 2(d)). These results demonstrate that mango peel and flesh extracts (at $60 \mu \mathrm{g} / \mathrm{mL}$ ) do not significantly alter ERK phosphorylation in MCF-7 cells.

\subsection{Effect of Mango Peel and Flesh Extracts on Intracellular} Calcium Signalling upon Adenosine Triphosphate Stimulation. MCF-7 cells were incubated with mango peel and flesh extracts (at 30 and $60 \mu \mathrm{g} / \mathrm{mL}$ ) from IW, NDM, and KP for $96 \mathrm{~h}$. Bolus addition of ATP at $100 \mu \mathrm{M}$ was then used to assess extract effects on $\left[\mathrm{Ca}^{2+}\right]_{\mathrm{I}}$ signalling (Figures 3-5). Untreated MCF-7 cells stimulated with ATP (control) induced a rapid rise in $\left[\mathrm{Ca}^{2+}\right]_{\mathrm{I}}$, followed by homeostatic recovery of $\left[\mathrm{Ca}^{2+}\right]_{\mathrm{I}}$ to basal levels (Figure 3(a)). Extracts from cultivar IW demonstrated that only the peel at $60 \mu \mathrm{g} / \mathrm{mL}$ significantly reduced relative peak $\left[\mathrm{Ca}^{2+}\right]_{\mathrm{I}}$ when stimulated with ATP compared to untreated cells (control, Figures 3(a) and 3(b)). Compared to the control, IW peel extract at $60 \mu \mathrm{g} / \mathrm{mL}$ also significantly increased the time to reach half peak relative $\left[\mathrm{Ca}^{2+}\right]_{\mathrm{I}}$ after ATP stimulation at $117.4 \pm 8.6 \mathrm{~s}$, as compared to control cells (95.2 $\pm 8.4 \mathrm{~s}$, Figure 3(c)), indicative of effects on calcium homeostatic mechanisms important in the recovery phase such as reduced sequestration/efflux of $\mathrm{Ca}^{2+}$ and/or increased sustained $\mathrm{Ca}^{2+}$ influx.

NDM peel extracts at 30 and $60 \mu \mathrm{g} / \mathrm{mL}$ and flesh extract from the same cultivar at $60 \mu \mathrm{g} / \mathrm{mL}$ significantly reduced the relative maximum peak $\left[\mathrm{Ca}^{2+}\right]_{\mathrm{I}}$, after ATP stimulation (Figures 4(a) and 4(b)). The peel extract at $60 \mu \mathrm{g} / \mathrm{mL}$ reduced relative peak $\left[\mathrm{Ca}^{2+}\right]_{\mathrm{I}}$ to the greatest extent and was the only treatment substantially delaying the time required to reach half peak relative $\left[\mathrm{Ca}^{2+}\right]_{\mathrm{I}}$ (Figures $4(\mathrm{a})$ and $4(\mathrm{c})$ ), with a significant delay in homeostatic calcium recovery of $209.4 \pm$ $11.9 \mathrm{~s}$ observed in cells treated with $60 \mu \mathrm{g} / \mathrm{mL}$ peel extract, compared to $89.4 \pm 6.7 \mathrm{~s}$ for control cells (Figure 4(c)).

An assessment of KP fruit revealed that the peel extract at $60 \mu \mathrm{g} / \mathrm{mL}$ and flesh extract at 30 and $60 \mu \mathrm{g} / \mathrm{mL}$ significantly reduced relative $\left[\mathrm{Ca}^{2+}\right]_{\mathrm{I}}$ (Figures 5(a) and 5(b)). However, none of the extracts produced a significant delay in calcium recovery compared to control cells (Figures 5(a) and 5(c)), which was a feature of IW and NDM peel extracts (at $60 \mu \mathrm{g} / \mathrm{mL})$. 


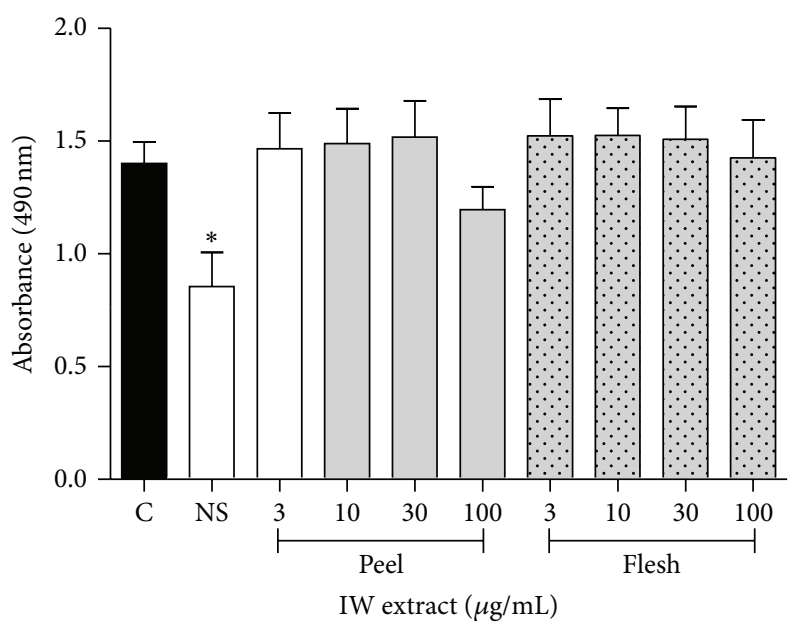

(a)

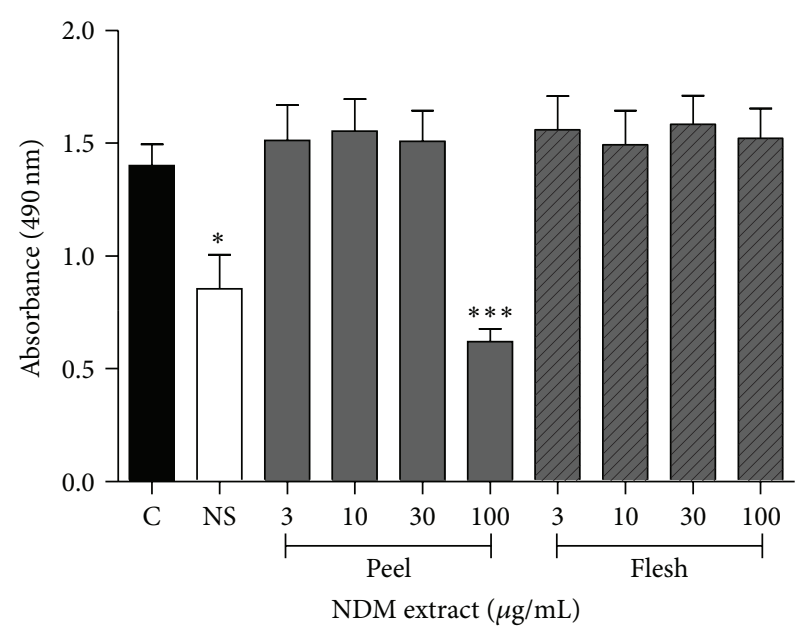

(b)

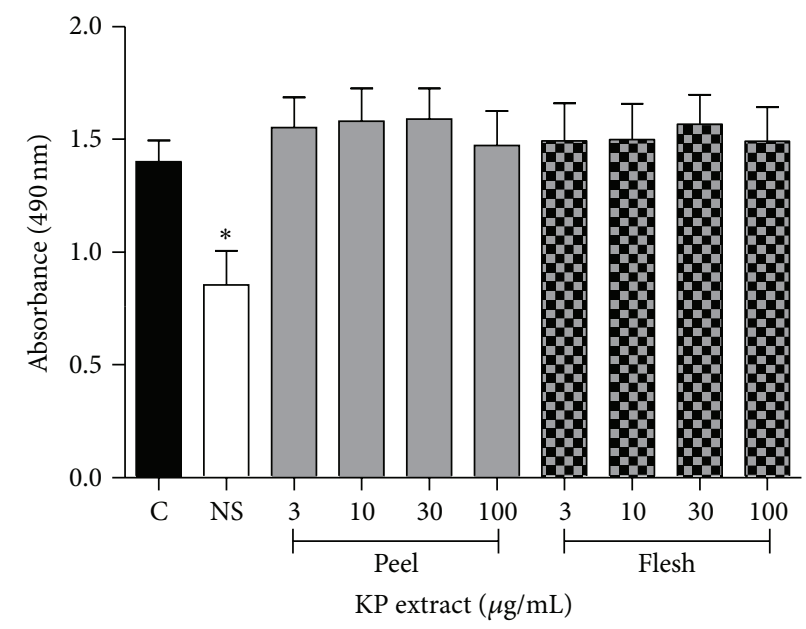

(c)

FIGURE 1: MCF-7 cell proliferation. Breast cell line MCF-7 was treated with increasing concentrations of IW (a), NDM (b), and KP (c) peel and flesh extracts for $96 \mathrm{~h}$. Proliferation was determined by Cell Titer $96 \mathrm{AQ}_{\mathrm{UEOuS}}$ One Cell Proliferation Assay. Columns, mean; bars, SE. ${ }^{*} P \leq 0.05$ versus control $(\mathrm{C})(n \geq 9) .{ }^{* *} P \leq 0.01$. ${ }^{* * *} P \leq 0.001$ no serum control.

\section{Discussion}

Phytochemicals are nonnutritive components in plant-based diets and some reports suggest that these dietary factors may play a role in the prevention of some cancers [8]. In this study, we evaluated the ability of mango peel and flesh extracts from three genetically distinct mango cultivars to inhibit proliferation of MCF-7 breast cancer cells. Of the extracts tested, only the NDM peel extract significantly inhibited the proliferation of hormone-sensitive MCF-7 cells. Comparative component analysis between mango cultivars and different tissues of the fruit (peel and flesh) was performed and has recently been published by our research team [32]. The peel of NDM revealed the presence of gallic acid and its galloylated derivatives in this tissue. Methyl gallate (methyl 3,4,5trihydroxybenzoate), the methyl ester of gallic acid, although present among all varieties and fruit parts tested [32], was most prevalent in NDM peel and may in part be associated with NDM peel extract's antiproliferative effect. This finding is supported by the study of Noratto and colleagues reporting that galloylated derivatives present in other mango varieties (Haden and Atualfo) have inhibitory properties on SW-480 colon carcinoma cell proliferation [6]. The authors suggested that the effects observed may result from G2/M cell cycle arrest elicited by these compounds [6].

At all developmental stages the peel of mango fruit contains higher levels of polyphenols than the flesh $[33,34]$. Our previous studies found comparable polyphenolic levels between both NDM and IW peel extracts [7]. This suggests total phenolic content alone is not responsible for NDM peel extract inhibitory effects on MCF-7 breast cancer cell growth and highlights the diversity of bioactive polyphenols between different mango cultivars. Other studies similarly report no relationship between plant extract (including avocado, guava, and prickly pear cactus stem) total phenolic content and antiproliferative effects in MCF-7 cells [11, 35-37]. To start exploring the possible mechanistic pathways by which NDM peel extract inhibits MCF-7 breast cancer cell growth, we 

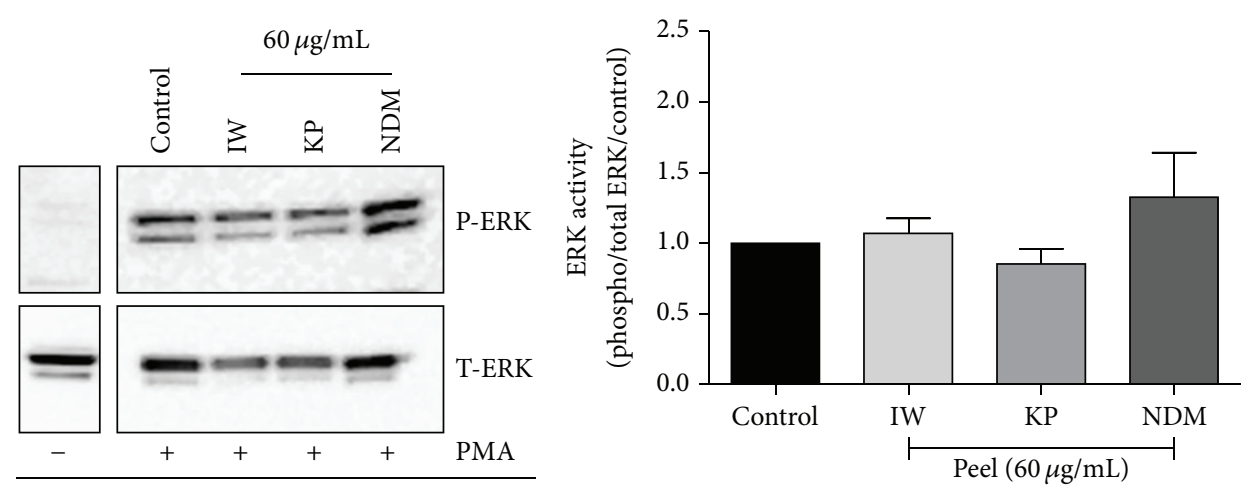

(a)
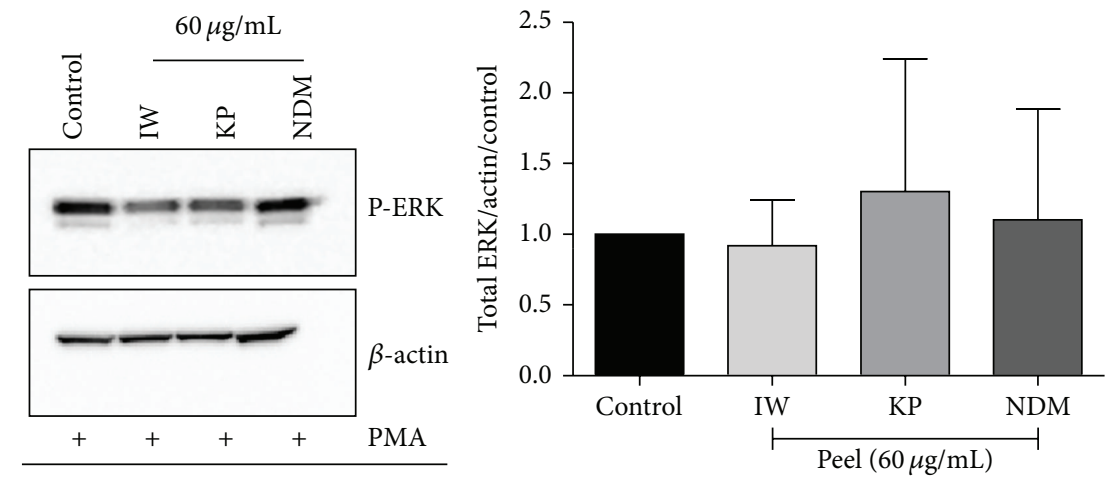

(b)
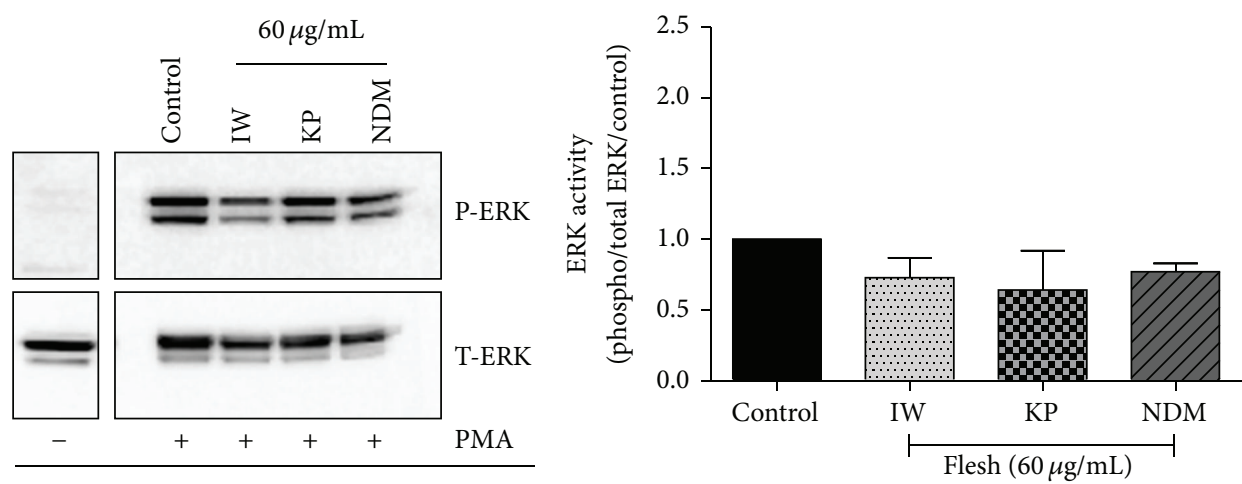

(c)
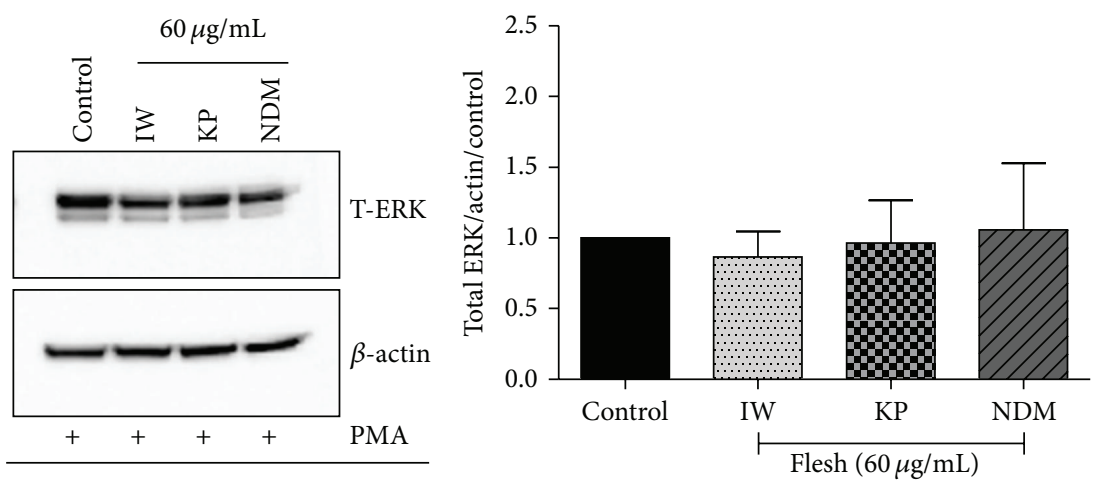

(d)

FIGURE 2: ERK activation in MCF-7 tumour cells. The phosphorylation of ERK (P-ERK) ((a) and (c)) and normalisation of total ERK (TERK) ((b) and (d)) in lysates from cells treated with peel and flesh extracts from mango cultivars IW, KP, and NDM were determined by immunoblotting. Bar graphs indicate quantification of at least 3 separate blots using Quantity One software. Data are expressed as mean \pm SE. ${ }^{*} P \leq 0.05$, significant difference from PMA-treated controls $(n \geq 3)$. 


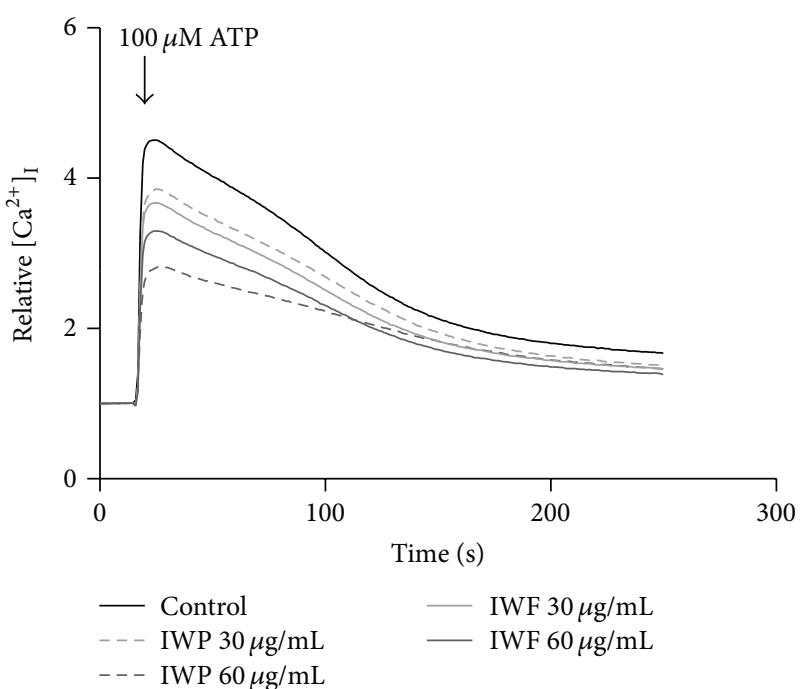

(a)

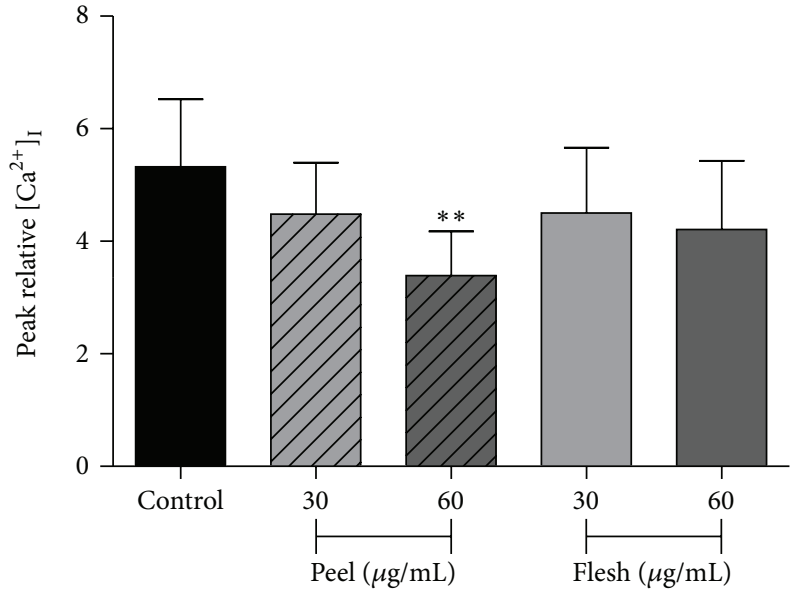

(b)

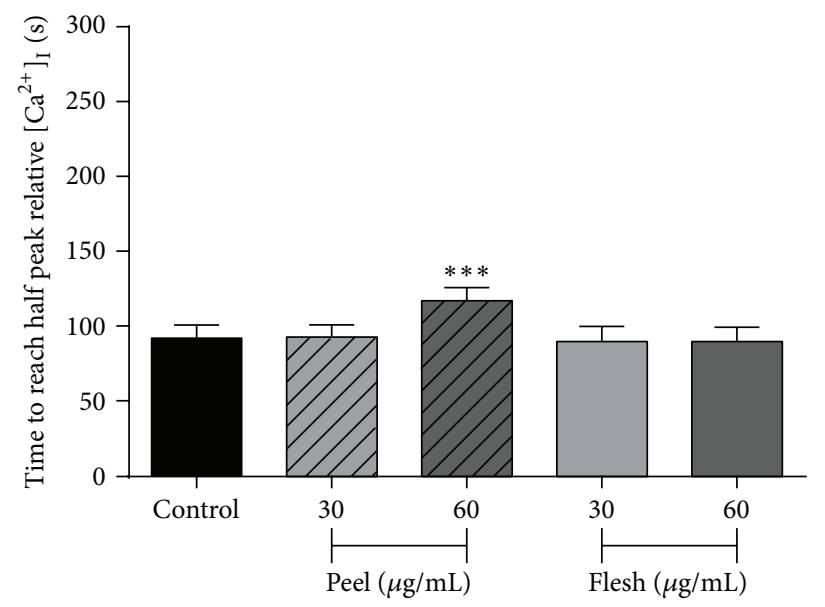

(c)

FIGURE 3: (a) Average relative $\left[\mathrm{Ca}^{2+}\right]_{\mathrm{I}}$ transients, (b) peak relative $\left[\mathrm{Ca}^{2+}\right]_{\mathrm{I}}$ response, and (c) time to reach half peak relative $\left[\mathrm{Ca}{ }^{2+}\right]_{\mathrm{I}}$ in $\mathrm{MCF}-7$ cells treated with IW peel (P) and flesh (F) extracts for $96 \mathrm{~h}$ and stimulated with ATP $(100 \mu \mathrm{M})$. Cells were loaded with Fluo- 4 AM dye, relative $\left[\mathrm{Ca}^{2+}\right]_{\mathrm{I}}$ was measured using FLIPR ${ }^{\text {TETRA }}$ and represented as response over baseline. Trace, mean $(n=9)$. Columns, means $(n=9) \pm$ S.D. ${ }^{*} P \leq 0.05 .{ }^{* *} P \leq 0.01$. ${ }^{* * *} P \leq 0.001$.

assessed mango extract effects on ERK phosphorylation and $\left[\mathrm{Ca}^{2+}\right]_{\mathrm{I}}$.

ERK phosphorylation regulates the expression of genes responsible for cellular processes including growth and differentiation [38]. Many breast cancer chemotherapeutic drugs elicit chemopreventive effects through modulating ERK phosphorylation $[39,40]$. Natural products have been shown to have antiproliferative effects through targeting the ERK1/2 protein. For example, extracts from edible leaves of Vernonia amygdalina attenuate ERK1/2 expression and inhibit proliferation of MCF-7 breast cancer cells [38]. In this study, we evaluated the ability of peel and flesh extracts from three different mango cultivars to alter ERK phosphorylation and expression. We found peel and flesh extracts did not significantly change ERK phosphorylation compared to controls, suggesting NDM peel extract mediates its antiproliferative effect via other intracellular targets.

Tumor promotion and progression can be mediated by $\left[\mathrm{Ca}^{2+}\right]_{\mathrm{I}}$ dependent signalling pathways that affect cellular processes including transcription, differentiation, cell cycle, and apoptosis [19]. Free cytosolic $\mathrm{Ca}^{2+}$, for example, is involved in the regulation of calcium/calmodulin-dependent kinase family of proteins to induce cell proliferation in breast tumorigenic cells [14]. In this study, we assessed whether peel and flesh extracts from different mango cultivars alter relative peak $\left[\mathrm{Ca}^{2+}\right]_{\mathrm{I}}$ and the recovery of $\left[\mathrm{Ca}^{2+}\right]_{\mathrm{I}}$ in MCF-7 breast cancer cells stimulated with ATP. The peel and flesh extracts of some mango cultivars reduced relative maximal peak $\left[\mathrm{Ca}^{2+}\right]_{\mathrm{I}}$ after ATP stimulation; however, NDM peel extract had the greatest effect among the treatments. Various 


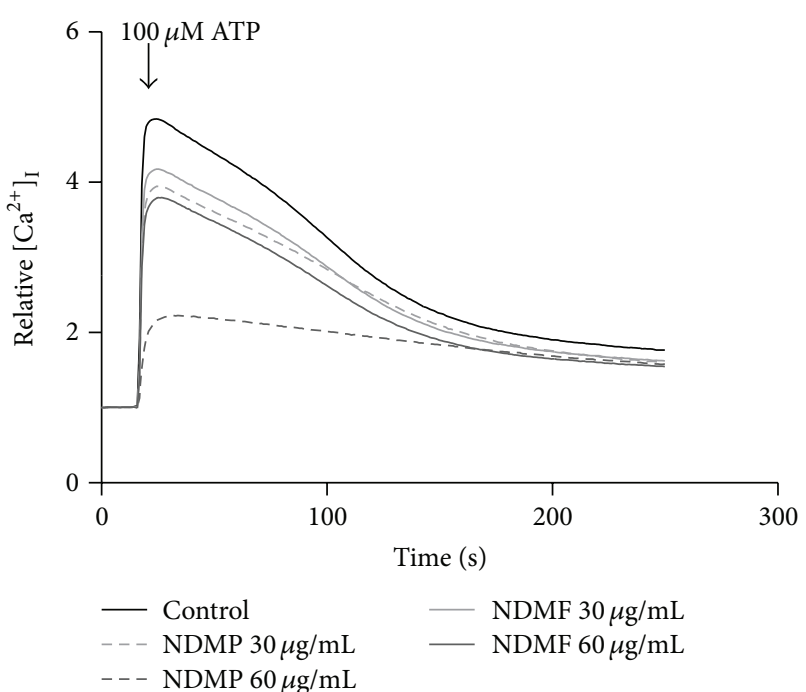

(a)

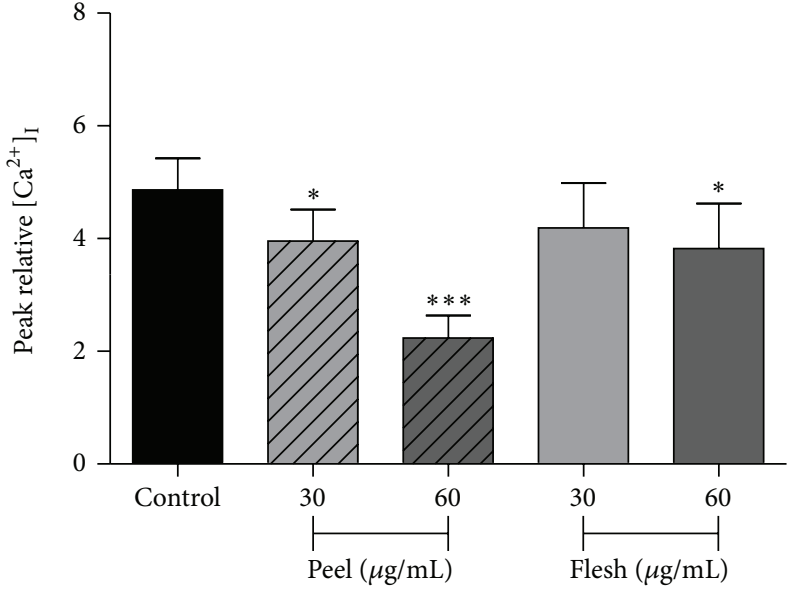

(b)

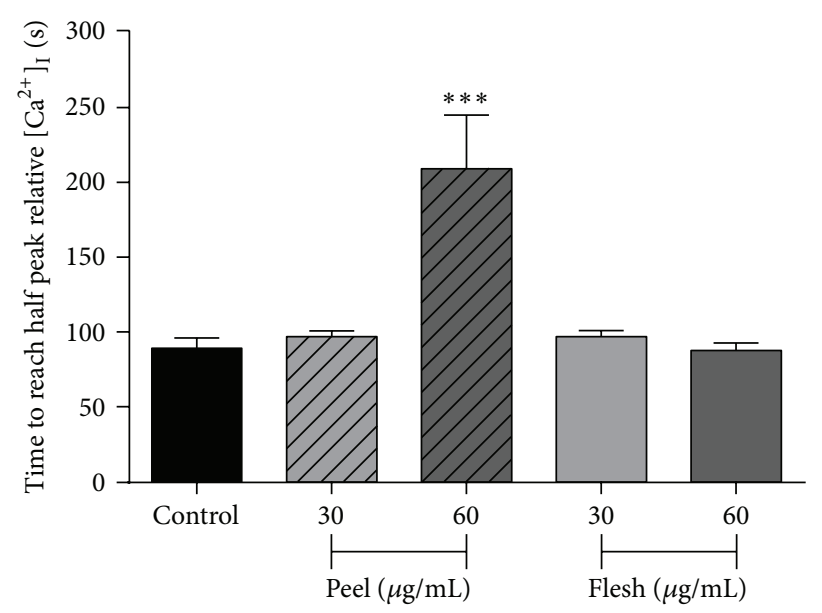

(c)

FIGURE 4: (a) Average relative $\left[\mathrm{Ca}^{2+}\right]_{\mathrm{I}}$ transients, (b) peak relative $\left[\mathrm{Ca}^{2+}\right]_{\mathrm{I}}$ response, and (c) time to reach half peak relative $\left[\mathrm{Ca}{ }^{2+}\right]_{\mathrm{I}}$ in $\mathrm{MCF}-7$ cells treated with NDM peel (P) and flesh (F) extracts for $96 \mathrm{~h}$ and stimulated with ATP $(100 \mu \mathrm{M})$. Cells were loaded with Fluo-4 AM dye; relative $\left[\mathrm{Ca}^{2+}\right]_{\mathrm{I}}$ was measured using $\operatorname{FLIPR}^{\text {TETRA }}$ and represented as response over baseline. Trace, mean $(n=9)$. Columns, means $(n=9) \pm$ S.D. ${ }^{*} P \leq 0.05 .{ }^{* *} P \leq 0.01$. ${ }^{* * *} P \leq 0.001$.

signalling targets may be responsible for the attenuated maximal $\left[\mathrm{Ca}^{2+}\right]_{\mathrm{I}}$ response to ATP by some mango extracts. These include potential effects on G-protein-coupled receptors, purinergic receptors (P2X and P2Y), phospholipase $\mathrm{C}$, inositol triphosphate $\left(\mathrm{IP}_{3}\right)$ receptor, and $\mathrm{Ca}^{2+}$ storage within the endoplasmic reticulum of MCF-7 breast cancer cells [19]. Altered activity in any one of these components could alter the peak $\left[\mathrm{Ca}^{2+}\right]_{\mathrm{I}}$ elicited by ATP and previous studies have demonstrated that plant-derived extracts and phytochemicals can interfere with many of these targets [41-43].

Peel extracts from both IW and NDM cultivars were observed to delay ATP-stimulated recovery of $\left[\mathrm{Ca}^{2+}\right]_{\mathrm{I}}$ in MCF-7 breast cancer cells. NDM peel extract had the greatest effect on recovery. Various signalling targets could be responsible for this observed delay in $\left[\mathrm{Ca}^{2+}\right]_{I}$ recovery to ATP.
Attenuated expression or activity of plasma membrane $\mathrm{Ca}^{2+}$ ATPases (PMCA) that actively pump $\mathrm{Ca}^{2+}$ from the cytosol and sarco/endoplasmic reticulum $\mathrm{Ca}^{2+}$-ATPases (SERCA) pumps that sequester $\mathrm{Ca}^{2+}$ into internal stores could account for reduced ability to recovery basal $\left[\mathrm{Ca}^{2+}\right]_{\mathrm{I}}$ levels after stimulation [19]. Phytochemicals and extracts derived from plants can interfere with multiple specific calcium signalling targets within cells, to decrease and delay the intracellular $\mathrm{Ca}^{2+}$ response to xenobiotic stimuli $[44,45]$. In this study, we demonstrated that different mango cultivar extracts could attenuate relative peak $\left[\mathrm{Ca}^{2+}\right]_{I}$ and prolong recovery of $\left[\mathrm{Ca}^{2+}\right]_{\mathrm{I}}$ to homeostasis in MCF-7 breast cancer cells stimulated with ATP. Compared to other mango fruit extracts, NDM peel extract demonstrated highly potent effects against both measured intracellular $\mathrm{Ca}^{2+}$ parameters. This may in 


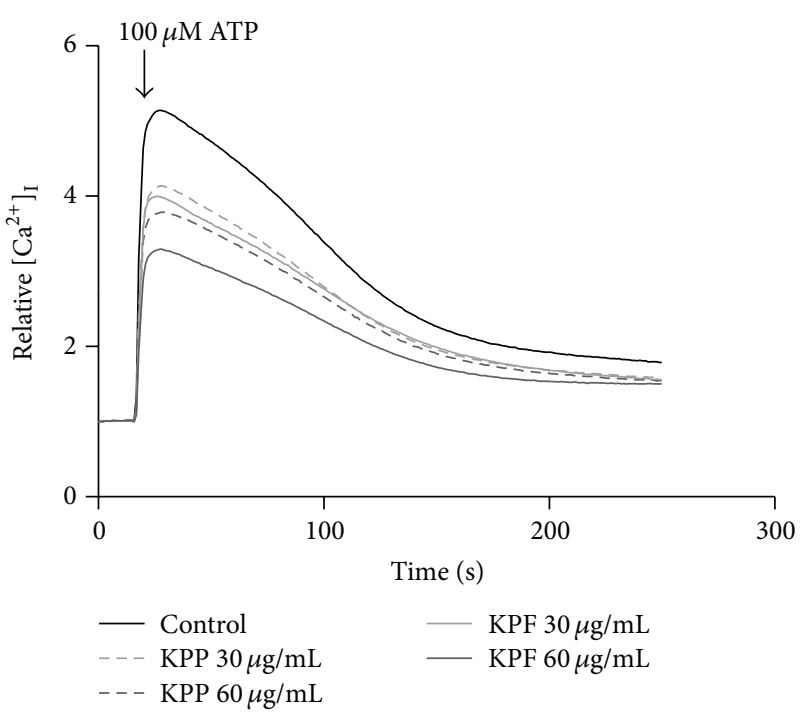

(a)

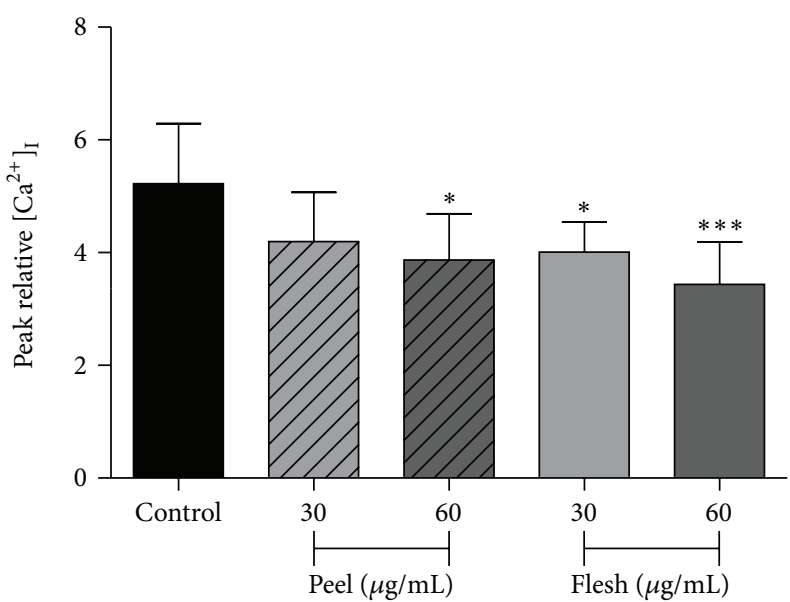

(b)

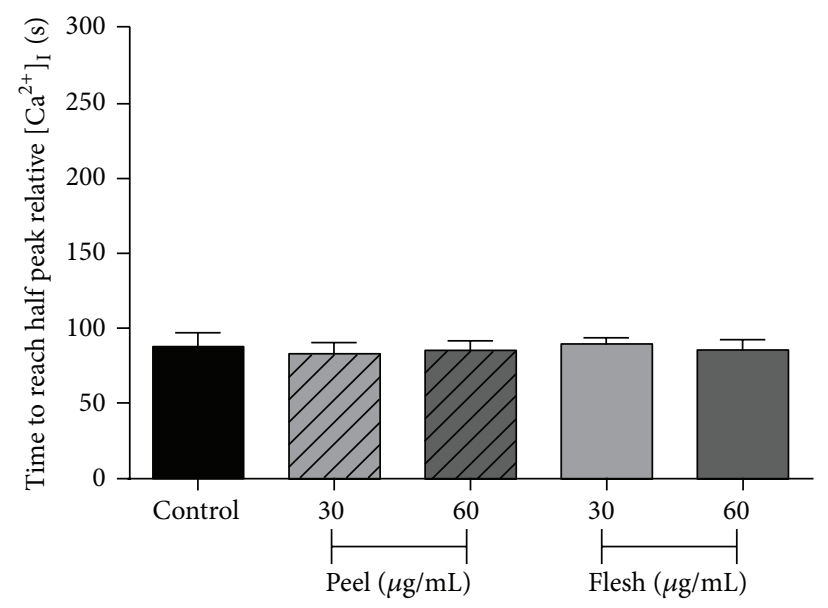

(c)

Figure 5: (a) Average relative $\left[\mathrm{Ca}^{2+}\right]_{\mathrm{I}}$ transients, (b) peak relative $\left[\mathrm{Ca}^{2+}\right]_{\mathrm{I}}$ response, and (c) time to reach half peak relative $\left[\mathrm{Ca}{ }^{2+}\right]_{\mathrm{I}}$ in $\mathrm{MCF}-7$ cells treated with KP peel (P) and flesh (F) extracts for $96 \mathrm{~h}$ and stimulated with ATP $(100 \mu \mathrm{M})$. Cells were loaded with Fluo-4 AM dye; relative $\left[\mathrm{Ca}^{2+}\right]_{\mathrm{I}}$ was measured using FLIPR ${ }^{\text {TETRA }}$ and represented as response over baseline. Trace, mean $(n=9)$. Columns, means $(n=9) \pm \operatorname{S.D}$. ${ }^{*} P \leq 0.05 .{ }^{* *} P \leq 0.01 .{ }^{* * *} P \leq 0.001$.

part be attributed to the presence of unique gallic acid derivatives in NDM peel and its characteristically high prevalence of methyl gallate, compared to other mango cultivars and tissues [32]. Findings by Sakaguchi and collaborators demonstrate cell death (HL-60RG, dRLh-84, HeLa, and PLC/PRF/5 cancer cells) induced by gallic acid can be prevented by the intracellular calcium chelator bis-(o-aminophenoxy)-N,N,N,N ${ }^{\prime}$ tetraacetic acid acetoxymethyl ester (BAPTA-AM) [46]. This report highlights gallic acid, and potentially derivatives of gallic acid found in NDM peel extract may modify $\left[\mathrm{Ca}^{2+}\right]_{\mathrm{I}}$ in MCF-7 cells leading to antiproliferative effects. IW peel extract displayed similar although more modest effects on $\left[\mathrm{Ca}^{2+}\right]_{\mathrm{I}}$ in MCF-7 cells compared to NDM peel extract and KP peel and flesh extracts reduced relative peak $\left[\mathrm{Ca}^{2+}\right]_{\mathrm{I}}$ but did not affect recovery of $\left[\mathrm{Ca}^{2+}\right]_{\mathrm{r}}$. The bioactive differences between extracts provide further evidence for diverse and complex phytochemical synergistic and antagonistic interactions within mango fruit tissues and between mango fruit cultivars [7]. Further work is now required to elucidate which phytochemicals and combinations of phytochemicals can delay calcium recovery, a feature characteristic of IW and NDM peel extracts. Future studies should also assess specific endogenous factors such as oestradiol that promote the proliferation of MCF-7 cells. Physiological concentrations of $17 \beta$ oestradiol have been reported to increase $\left[\mathrm{Ca}^{2+}\right]_{\mathrm{I}}$ in MCF-7 cells $[47,48]$. Elucidating the effect of mango extracts and gallic acid derivatives (found in NDM peel extracts) in the presence of oestradiol or other factors that stimulate proliferation and alter $\left[\mathrm{Ca}^{2+}\right]_{I}$ could provide further evidence to support the relationship between mango interfruit and intrafruit (peel and flesh) extract variability in $\left[\mathrm{Ca}^{2+}\right]_{\mathrm{I}}$ signalling and antiproliferative effects in MCF-7 breast cancer cells. 


\section{Conclusion}

In this study, we compared the effects of peel and flesh extracts from three genetically distinct mango cultivars for their antiproliferative effects on MCF-7 breast cancer cells. Of all the extracts tested, only the NDM peel extract exhibited growth inhibitory effects, and this correlated with a unique composition of gallic acid derivatives [32] and a more pronounced effect on $\mathrm{Ca}^{2+}$ signalling. Further selective compound bioactive studies are now required to validate which compounds within NDM peel extracts may potentiate and are responsible for these bioactivities. Future studies may also assess whether these compounds [32] and/or their combinations affect $\mathrm{Ca}^{2+}$ dependent signalling pathways such as the calcium/calmodulin-dependent kinase family of proteins in human MCF-7 breast cancer cells. Our study identified mango interfruit and intrafruit (peel and flesh) extract variability on proliferation and is the first study to report mango fruit extract effects on $\mathrm{Ca}^{2+}$ signalling in MCF-7 breast cancer cells.

\section{Abbreviations}

IW: Irwin

NDM: Nam Doc Mai

KP: $\quad$ Kensington Pride

ERK: Extracellular signal-regulated kinase

$\left[\mathrm{Ca}^{2+}\right]_{\mathrm{I}}$ : Intracellular calcium concentration.

\section{Conflict of Interests}

The authors declare that there is no conflict of interests regarding the publication of this paper.

\section{Acknowledgments}

This work was supported by an Australian Research Council Linkage Grant (LP0883644) and an Australian Postgraduate Award to Meng-Wong Taing. The authors thank Ian Bally, Queensland Department of Agriculture, Fisheries and Forestry, for provision of mango fruit from the Australian Mango Genebank.

\section{References}

[1] J. K. Lin, "Cancer chemoprevention by tea polyphenols through modulating signal transduction pathways," Archives of Pharmacal Research, vol. 25, no. 5, pp. 561-571, 2002.

[2] S. C. Thomasset, D. P. Berry, G. Garcea, T. Marczylo, W. P. Steward, and A. J. Gescher, "Dietary polyphenolic phytochemicalspromising cancer chemopreventive agents in humans? A review of their clinical properties," International Journal of Cancer, vol. 120, no. 3, pp. 451-458, 2007.

[3] J. T. Pierson, R. G. Dietzgen, P. N. Shaw, S. J. Roberts-Thomson, G. R. Monteith, and M. J. Gidley, "Major Australian tropical fruits biodiversity: bioactive compounds and their bioactivities," Molecular Nutrition and Food Research, vol. 56, no. 3, pp. 357-387, 2012.
[4] R. E. Litz, The Mango: Botany, Production and Uses, CAB International, Cambridge, Mass, USA, 2nd edition, 2009.

[5] M. W. Taing, J. T. Pierson, P. N. Shaw et al., "Mango (Mangifera indica L.) peel extract fractions from different cultivars differentially affect lipid accumulation in 3T3-L1 adipocyte cells," Food and Function, vol. 4, no. 3, pp. 481-491, 2013.

[6] G. D. Noratto, M. C. Bertoldi, K. Krenek, S. T. Talcott, P. C. Stringheta, and S. U. Mertens-Talcott, "Anticarcinogenic effects of polyphenolics from mango (Mangifera indica) varieties," Journal of Agricultural and Food Chemistry, vol. 58, no. 7, pp. 4104-4112, 2010.

[7] M. W. Taing, J. T. Pierson, V. L. T. Hoang et al., "Mango fruit peel and flesh extracts affect adipogenesis in 3T3-L1 cells," Food and Function, vol. 3, no. 8, pp. 828-836, 2012.

[8] N. Khan, F. Afaq, and H. Mukhtar, "Cancer chemoprevention through dietary antioxidants: progress and promise," Antioxidants and Redox Signaling, vol. 10, no. 3, pp. 475-510, 2008.

[9] G. L. Russo, "Ins and outs of dietary phytochemicals in cancer chemoprevention," Biochemical Pharmacology, vol. 74, no. 4, pp. 533-544, 2007.

[10] L. S. Adams, S. Phung, N. Yee, N. P. Seeram, L. Li, and S. Chen, "Blueberry phytochemicals inhibit growth and metastatic potential of MDA-MB-231 breast cancer cells through modulation of the phosphatidylinositol 3-kinase pathway," Cancer Research, vol. 70, no. 9, pp. 3594-3605, 2010.

[11] P. García-Solís, E. M. Yahia, V. Morales-Tlalpan, and M. DíazMuñoz, "Screening of antiproliferative effect of aqueous extracts of plant foods consumed in México on the breast cancer cell line MCF-7,' International Journal of Food Sciences and Nutrition, vol. 60, no. 6, pp. 32-46, 2009.

[12] Y.-J. Surh, "Cancer chemoprevention with dietary phytochemicals," Nature Reviews Cancer, vol. 3, no. 10, pp. 768-780, 2003.

[13] D. Boivin, S. Lamy, S. Lord-Dufour et al., "Antiproliferative and antioxidant activities of common vegetables: a comparative study," Food Chemistry, vol. 112, no. 2, pp. 374-380, 2009.

[14] J. M. Schmitt, E. Abell, A. Wagner, and M. A. Davare, "ERK activation and cell growth require CaM kinases in MCF-7 breast cancer cells," Molecular and Cellular Biochemistry, vol. 335, no. 1-2, pp. 155-171, 2010.

[15] C. C. Chen, W.-R. Lee, and S. Safe, "Egr-1 is activated by 17betaestradiol in MCF-7 cells by mitogen-activated protein kinasedependent phosphorylation of ELK-1," Journal of Cellular Biochemistry, vol. 93, no. 5, pp. 1063-1074, 2004.

[16] T. Improta-Brears, A. R. Whorton, F. Codazzi, J. D. York, T. Meyer, and D. P. Mcdonnel, "Estrogen-induced activation of mitogen-activated protein kinase requires mobilization of intracellular calcium," Proceedings of the National Academy of Sciences of the United States of America, vol. 96, no. 8, pp. 46864691, 1999.

[17] J. H. Gutzman, S. E. Nikolai, D. E. Rugowski, J. J. Watters, and L. A. Schuler, "Prolactin and estrogen enhance the activity of activating protein 1 in breast cancer cells: role of extracellularly regulated kinase 1/2-mediated signals to c-fos," Molecular Endocrinology, vol. 19, no. 7, pp. 1765-1778, 2005.

[18] K. Dampier, E. A. Hudson, L. M. Howells, M. M. Manson, R. A. Walker, and A. Gescher, "Differences between human breast cell lines in susceptibility towards growth inhibition by genistein," British Journal of Cancer, vol. 85, no. 4, pp. 618-624, 2001.

[19] G. R. Monteith, D. McAndrew, H. M. Faddy, and S. J. RobertsThomson, "Calcium and cancer: targeting $\mathrm{Ca}^{2+}$ transport," Nature Reviews Cancer, vol. 7, no. 7, pp. 519-530, 2007. 
[20] D. P. Drew, N. Krichau, K. Reichwald, and H. T. Simonsen, "Guaianolides in apiaceae: perspectives on pharmacology and biosynthesis," Phytochemistry Reviews, vol. 8, no. 3, pp. 581-599, 2009.

[21] R. Kuttan, P. Bhanumathy, K. Nirmala, and M. C. George, "Potential anticancer activity of turmeric (Curcuma longa)," Cancer Letters, vol. 29, no. 2, pp. 197-202, 1985.

[22] S. M. Wilkinson and M. H. Beck, "Allergic contact dermatitis from menthol in peppermint," Contact Dermatitis, vol. 30, no. 1, pp. 42-43, 1994.

[23] A. M. Bode and Z. Dong, “The two faces of capsaicin," Cancer Research, vol. 71, no. 8, pp. 2809-2814, 2011.

[24] N. L. Dillon, I. S. E. Bally, C. L. Wright, L. Hucks, D. J. Innes, and R. G. Dietzgen, "Genetic diversity of the Australian National Mango Genebank," Scientia Horticulturae, vol. 150, pp. 213-226, 2013.

[25] R. J. Schnell, J. S. Brown, C. T. Olano, A. W. Meerow, R. J. Campbell, and D. N. Kuhn, "Mango genetic diversity analysis and pedigree inferences for Florida cultivars using microsatellite markers," Journal of the American Society for Horticultural Science, vol. 131, no. 2, pp. 214-224, 2006.

[26] A. U. Malik and Z. Singh, "Pre-storage application of polyamines improves shelf-life and fruit quality of mango," Journal of Horticultural Science \& Biotechnology, vol. 80, no. 3, pp. 363369, 2005.

[27] N. H. Daud, C. S. Aung, A. K. Hewavitharana et al., "Mango extracts and the mango component mangiferin promote endothelial cell migration," Journal of Agricultural and Food Chemistry, vol. 58, no. 8, pp. 5181-5186, 2010.

[28] C. J. Goodwin, S. J. Holt, S. Downes, and N. J. Marshall, "Microculture tetrazolium assays: a comparison between two new tetrazolium salts, XTT and MTS," Journal of Immunological Methods, vol. 179, no. 1, pp. 95-103, 1995.

[29] D. McAndrew, D. M. Grice, A. A. Peters et al., "ORAI1-mediated calcium influx in lactation and in breast cancer," Molecular Cancer Therapeutics, vol. 10, no. 3, pp. 448-460, 2011.

[30] W. J. Lee, G. R. Monteith, and S. J. Roberts-Thomson, "Calcium transport and signaling in the mammary gland: targets for breast cancer," Biochimica et Biophysica Acta, vol. 1765, no. 2, pp. 235-255, 2006.

[31] D. M. Grice, I. Vetter, H. M. Faddy, P. A. Kenny, S. J. RobertsThomson, and G. R. Monteith, "Golgi calcium pump secretory pathway calcium ATPase 1 (SPCA1) is a key regulator of Insulinlike Growth Factor Receptor (IGF1R) processing in the basallike breast cancer cell line MDA-MB-231," Journal of Biological Chemistry, vol. 285, no. 48, pp. 37458-37466, 2010.

[32] J. T. Pierson, G. R. Monteith, S. J. Roberts-Thomson, R. G. Dietzgen, M. J. Gidley, and P. N. Shaw, "Phytochemical extraction, characterisation and comparative distribution across four mango (Mangifera indica L.) fruit varieties," Food Chemistry, vol. 149, pp. 253-263, 2014.

[33] M. Masibo and H. Qian, "Major mango polyphenols and their potential significance to human health," Comprehensive Reviews in Food Science and Food Safety, vol. 7, no. 4, pp. 309-319, 2008.

[34] S. M. R. Ribeiro, L. C. A. Barbosa, J. H. Queiroz, M. Knödler, and A. Schieber, "Phenolic compounds and antioxidant capacity of Brazilian mango (Mangifera indica L.) varieties," Food Chemistry, vol. 110, no. 3, pp. 620-626, 2008.

[35] Y. F. Chu, J. Sun, X. Wu, and R. H. Liu, "Antioxidant and antiproliferative activities of common vegetables," Journal of Agricultural and Food Chemistry, vol. 50, no. 23, pp. 6910-6916, 2002.
[36] S. S. Percival, S. T. Talcott, S. T. Chin, A. C. Mallak, A. LoundsSingleton, and J. Pettit-Moore, "Neoplastic transformation of BALB/3T3 cells and cell cycle of HL-60 cells are inhibited by mango (Mangifera indica L.) juice and mango juice extracts," Journal of Nutrition, vol. 136, no. 5, pp. 1300-1304, 2006.

[37] J. Sun, Y.-F. Chu, X. Wu, and R. H. Liu, "Antioxidant and antiproliferative activities of common fruits," Journal of Agricultural and Food Chemistry, vol. 50, no. 25, pp. 7449-7454, 2002.

[38] E. B. Izevbigie, J. L. Bryant, and A. Walker, "A novel natural inhibitor of extracellular signal-regulated kinases and human breast cancer cell growth," Experimental Biology and Medicine, vol. 229, no. 2, pp. 163-169, 2004.

[39] N. Atanaskova, V. G. Keshamouni, J. S. Krueger, J. A. Schwartz, F. Miller, and K. B. Reddy, "MAP kinase/estrogen receptor cross-talk enhances estrogen-mediated signaling and tumor growth but does not confer tamoxifen resistance," Oncogene, vol. 21, no. 25, pp. 4000-4008, 2002.

[40] A. Adeyinka, Y. Nui, T. Cherlet, L. Snell, P. H. Watson, and L. C. Murphy, "Activated mitogen-activated protein kinase expression during human breast tumorigenesis and breast cancer progression," Clinical Cancer Research, vol. 8, no. 6, pp. 1747-1753, 2002.

[41] K. M. Witherup, R. W. Ransom, A. C. Graham et al., "Martinelline and martinellic acid, novel G-protein linked receptor antagonists from the tropical plant Martinella iquitosensis (Bignoniaceae)," Journal of the American Chemical Society, vol. 117, no. 25, pp. 6682-6685, 1995.

[42] Y. Albert Yen, M. Herenyiova, and G. Weber, "Quercetin: synergistic action with carboxyamidotriazole in human breast carcinoma cells," Life Sciences, vol. 57, no. 13, pp. 1285-1292, 1995.

[43] Y. Guo, Y. J. Hong, H.-J. Jang et al., "Octyl gallate inhibits ATP-induced intracellular calcium increase in PC12 cells by inhibiting multiple pathways," Korean Journal of Physiology and Pharmacology, vol. 14, no. 1, pp. 21-28, 2010.

[44] A. O. da Conceição, L. Takser, and J. Lafond, “Effect of St. John's wort standardized extract and hypericin on in vitro placental calcium transport," Journal of Medicinal Food, vol. 13, no. 4, pp. 934-942, 2010.

[45] Y. A. Mahmmoud, "Modulation of protein kinase C by curcumin; inhibition and activation switched by calcium ions," British Journal of Pharmacology, vol. 150, no. 2, pp. 200-208, 2007.

[46] N. Sakaguchi, M. Inoue, and Y. Ogihara, "Reactive oxygen species and intracellular $\mathrm{Ca}^{2}$, common signals for apoptosis induced by gallic acid," Biochemical Pharmacology, vol. 55, no. 12, pp. 1973-1981, 1998.

[47] W. Thomas, N. Coen, S. Faherty, C. Ó. Flatharta, and B. J. Harvey, "Estrogen induces phospholipase A2 activation through ERK1/2 to mobilize intracellular calcium in MCF-7 cells," Steroids, vol. 71, no. 3, pp. 256-265, 2006.

[48] C. Szatkowski, J. B. Parys, H. Ouadid-Ahidouch, and F. Matifat, "Inositol 1,4,5-trisphosphate-induced $\mathrm{Ca}^{2+}$ signalling is involved in estradiol-induced breast cancer epithelial cell growth," Molecular Cancer, vol. 9, article 156, 2010. 

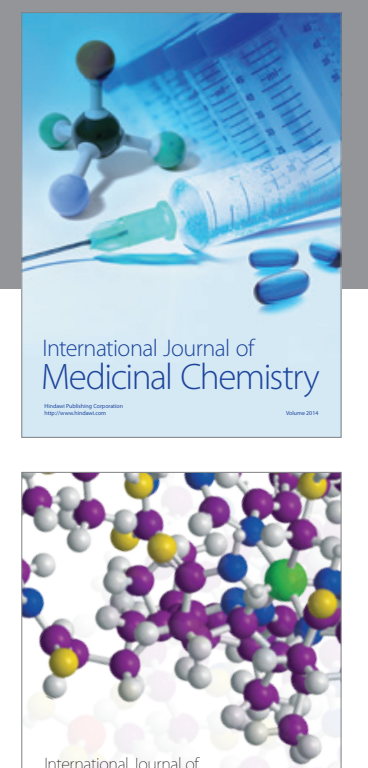

\section{Carbohydrate} Chemistry

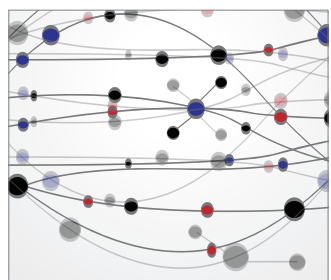

The Scientific World Journal
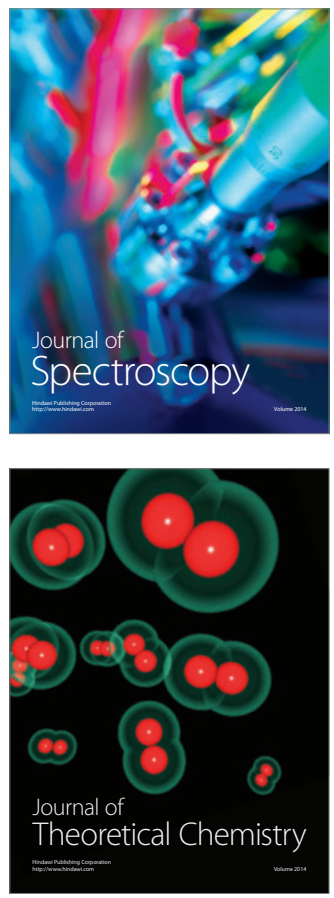
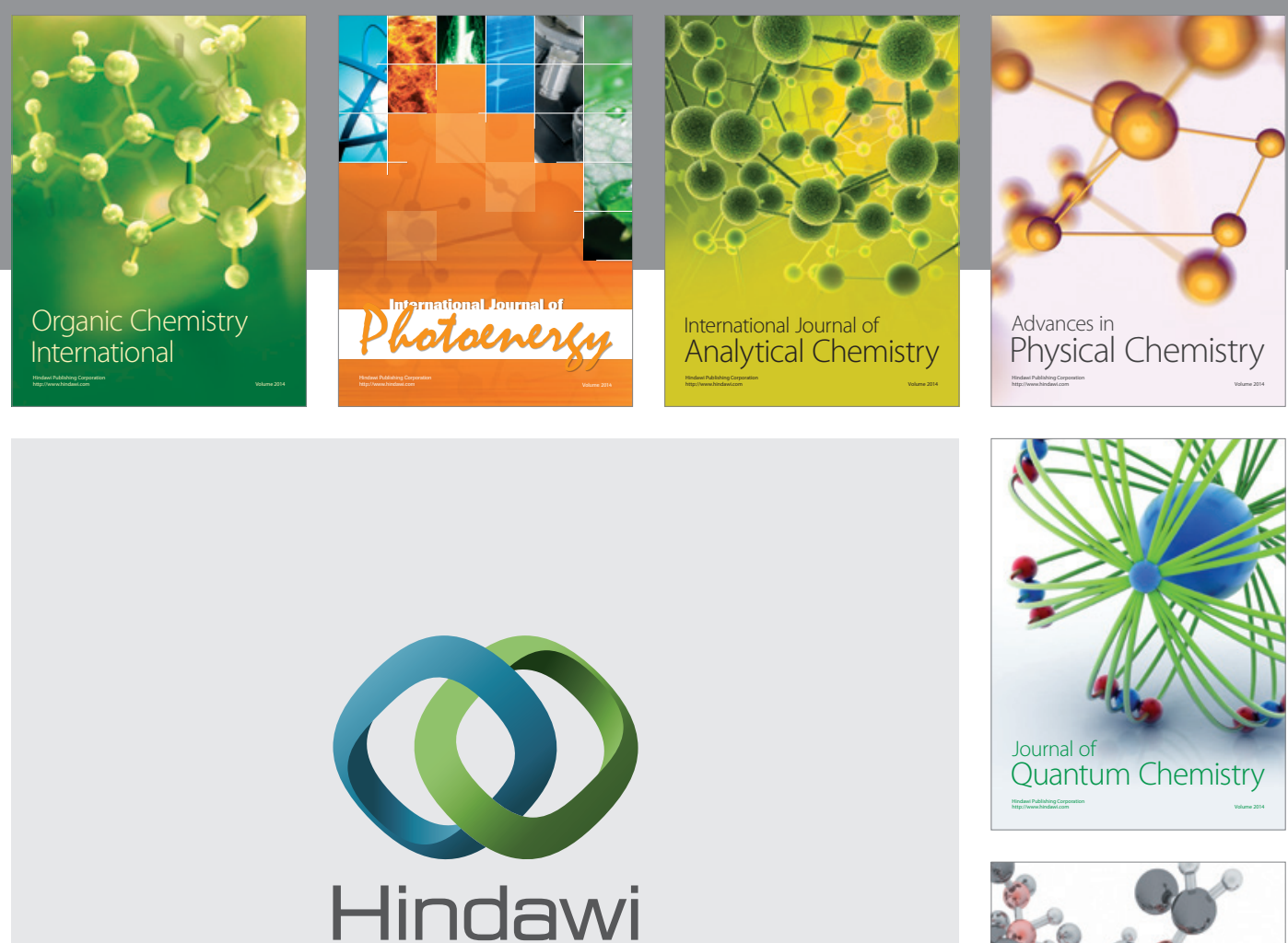

Submit your manuscripts at

http://www.hindawi.com

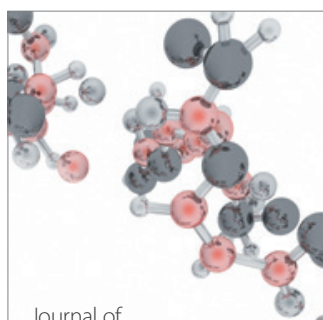

Analytical Methods

in Chemistry

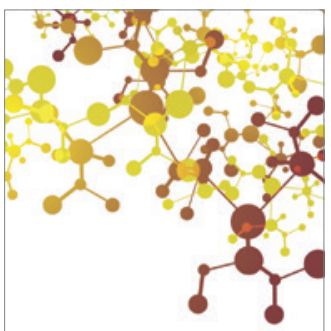

Journal of

Applied Chemistry

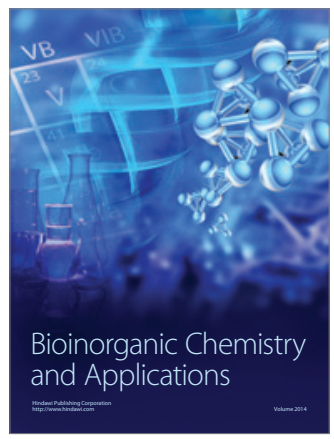

Inorganic Chemistry
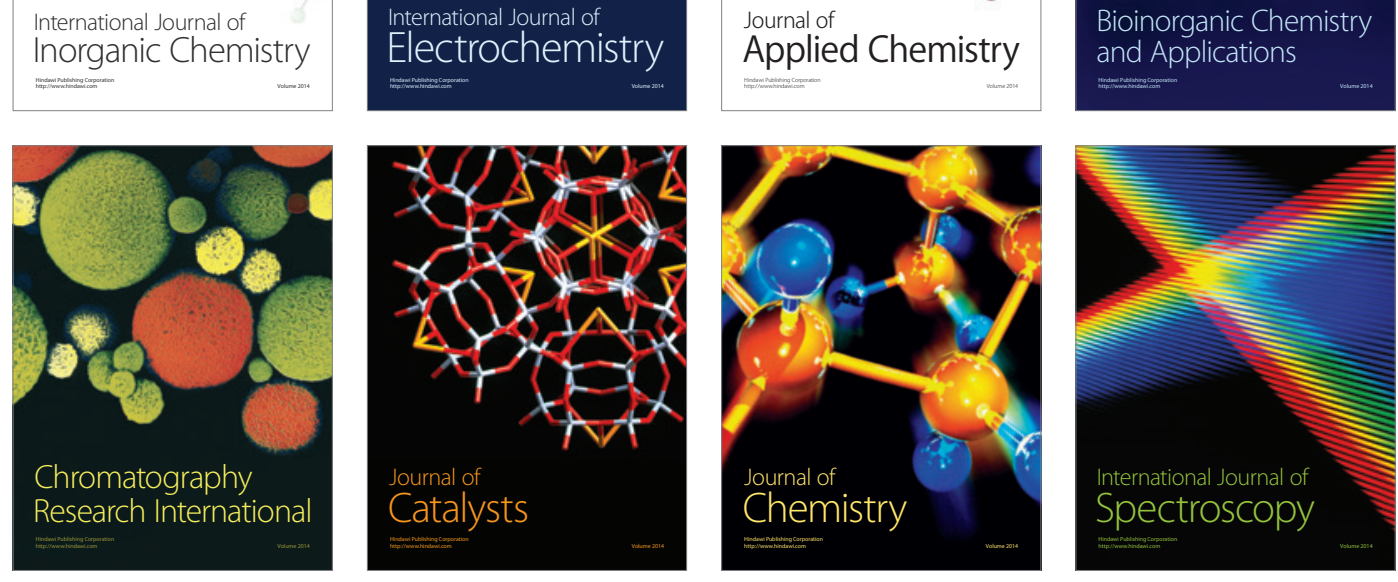